\title{
PBL DENGAN PENDEKATAN MULTIPLE REPRESENTATION TERHADAP KEMAMPUAN BERPIKIR KRITIS DITINJAU DARI KEMAMPUAN KOLABORASI
}

\author{
Godevila Sriyati Wela ${ }^{1}$, Chandra Sundaygara ${ }^{2}$, Hestiningtyas Yuli Pratiwi ${ }^{3}$. \\ vilawela@gmail.com
}

\begin{abstract}
Abstrak. Penelitian ini bertujuan untuk mengetahui pengaruh problem based learning dengan pendekatan multiple representation terhadap kemampuan berpikir kritis ditunjau dari kemampuan kolaborasi. Desain penelitian menggunakan quasi eksperiment dengan rancangan posttest only group design. Teknik pengambilan sampel menggunakan purposive sampling dengan instrumen penelitian adalah lembar observasi dan soal tes. Hasil penelitian menunjukan (i) terdapat perbedaan kemampuan berpikir kritis antara siswa yang diajar menggunakan model PBL dengan pendekatan multiple representation dan yang diajar dengan model PBL, ini dilihat dari nilai hasil perhitungan uji anova dua jalur yaitu sig $0,000<0,05$. (ii) Terdapat perbedaan kemampuan berpikir kritis antara siswa yang bekemampuan kolaborasi tinggi dengan yang berkemampuan kolaborasi rendah, hal ini terlihat dari nilai sig. $0,000<0,05$. (iii) Terdapat pengaruh interaksi antara model PBL dengan pendekatan multiple representation dan kemampuan kolaborasi terhadap kemampuan berpikir kritis, ini dilihat dari nilai sig. $0,044<0,05$. Sehingga disimpulkan bahwa model PBL dengan pendekatan multiple representation berpengaruh terhadap kemampuan berpikir kritis ditinjau dari kemampuan kolaborasi.
\end{abstract}

\section{Kata Kunci:PBL; Multiple Representation; Berpikir Kritis; Kolaborasi}

\section{PENDAHULUAN}

Sala satu disiplin ilmu yang dapat meningkatkan kemampuan berpikir kritis siswa adalah fisika karena secara langsung berhubungan dengan kehidupan sehari-hari yang menuntun individu untuk mempelajari konsep-konsep yang berkaitan dengan gejala alam dalam kehidupan setiap hari (Al-Fikry, Yusrizal \& Syukri, 2018). Kenyataannya pembelajaran fisika masih disajikan dengan penggunaan metode penghafalan rumus yang mengakibatkan ketidakmampuan siswa dalam menerapkan konsep untuk menyelesaikan persoalan yang berkaitan dengan kehidupan nyata. Temuan lain menunjukan guru cenderung menggunakan model pembelajaran konvesional yang menyebabkan siwa selalu pasif dalam proses pembelajaran (Respatiningrum, Sunardi \& Akhyar, 2017). Hal ini mengakibatkan seabagian siswa beranggapan bahwa belajar fisika kurang menarik dan membosankan karena selalu karena selalu belajar dengan angka dan rumus (Irawati dalam Al-Fikry et al., 2018). Hal ini tentunya berpengaruh pada pola berpikir kritis dan kemampuan analisis siswa dalam mendapatkan solusi yang kreatif terhadap pemecahan masalah(Sipayung, Rahmatsyah, Sani \& Lubis, 2019).

Abad 21 menekankan dan mengharuskan siswa untuk mengembangkan kemampuan berpikir kritis agar mampu melihat suatu situasi, menganalisis dan menemukan solusi yang tepat (Nurkholifah \& Mayasari, 2018). Salah satu tuntutan dunia pendidikan saat ini adalah siswa dapat mengembangkan kapasitas untuk berpikir dan salah satunya adalah keterampilan berpikir kritis. Fakta yang terjadi seperti yang diungkapkan oleh Novtiar \& Aripin (2017); Mustajab, Senen \& Waspada (2018). Hal didukung dari hasil survei oleh lembaga OECD dan PISA tahun 
2018, menunjukan penurunan yang signifikan dari peringkat 62 dengan skor 403 pada tahun 2015, menjadi peringkat ke 71 dengan skor 376 (Detiknew.com, 2019). Melihat permasalahan tersebut guru perlu memilih model pembelajaran yang memiliki student center dan salah satu solusi yang dapat mengatasi masalah tersebut adalah penerapan model Problem Based Learning (Farisi, Hamid \& Melvina, 2017).

Pembelajaran berbasis masalah (PBL) adalah suatu metode yang berorientasi pada masalah yang dijumpai dalam lingkungan sekitar sehingga dapat membangkitkan cara berpikir kritis seseorang termasuk didalamnya belajar serta bagaimana belajar berlangsung (Al-Fikry et al., 2018). Pada pelaksanaannya model problem based learning, masih memiliki beberapa kekurangan seperti kesulitan dalam memahami dan memecahkan masalah yang disajikan (Haryanti, 2017). Kesulitan memahami dan memecahkan masalah disebabkan karena siswa telah terbiasa dengan hanya menggunakan rumus matematis dalam menyelesaikan soal matematis. Kelemahan lainnya juga siswa kesulitan dalam memahami masalah yang disajikan, sehingga menyebabkan pemecahan masalah membutuhkan waktu yang lama (Sundaygara \& Gaharin, 2017). Menerapkan pendekatan multiple representation dapat mengatasi kesulitan yang terjadi dalam kegiatan belajar (Hasbullah, Halim \& Yurizal, 2018; Larasati, Ibnu \& Santoso, 2019).

Pendekatan multiple representation merupakan suatu pendekatan yang dalam penyajian menggabungkan grafik, gambar, teks serta simbol yang dapat meningkatkan pemahaman peserta didik serta berpartisipasi langsung secara aktif dalam proses pembelajaran (Doyan, Taufik \& Anjani, 2018). Penggunaan multiple representation menjadikan suatu masalah abstrak menjadi konkrit dalam semua ranah tinjauan (Hasbullah et al., 2018). Lebih lanjut Sundaygara \& Gaharin (2017) mengungkapkan melalui penggunaan multi representasi siswa mampu mengevaluasi pemecahan masalah dan berpengaruh terhadap pemahaman konsep yang benar. Penelitian terdahulu yang dilakukan oleh Marpaung \& Simanjuntak (2018); Ardiansyah, Erikanto \& Rosidin (2019), penerapan pendekatan ini dapat melatih kemampuan berpikir kritis.

Selain model pembelajaran, kemampuan kolaborasi juga mengakibatkan peningkatan hasil belajar (Hakkinen et al., 2016 dalam Hermawan et al., 2017). Siswa dapat bekerja sama dalam perbedaan kelompok atau dengan individu yang berbeda sebagai modal dalam menghadapi era globalisasi (Hermawan et al., 2017). Penggunaan kolaborasi menciptakan proses pembelajaran yang efektif di kelas (Fitriyani, Jalmo \& Yolida, 2019). Pembelajaran dengan berkolaborasi siswa dapat meningkatkan nilai kerja sama yaitu mampu menerima pendapat yang berbeda dari setiap individu untuk mencapai dan meningkatkan nilai (Burke, 2011 dalam Haryanti, 2017).

\section{METODE PENELITIAN}

Jenis penelitian ini menggunakan penelitian quasi eksperimen. Desainnya menggunakan post only group design, yaitu dengan pemberian tes kepada kedua kelompok yang dilaksanakan setelah perlakuan diberikan. Populasi dalam penelitian ini adalah siswa kelas VIII SMPN 2 Singosari tahun ajaran 2019/2020 dan sampel diambil dari populasi menggunakan teknik purposive sampling, yang terdiri dari 1 kelas kelompok kontrol dan 1 kelas untuk ekperimen. Kelompok eksperimen yaitu siswa kelas VIII D yang diberi perlakuan menggunakan model problem based learning dengan pendekatan multiple representation. Sedangkan kontrol yaitu kelas VIII B yang diberi menggunakan model problem based learning. Instrumen penelitian adalah lembar observasi untuk mengukur kemampuan kolaborasi siswa dan LKS serta soal tes berbentuk uraian untuk mengukur kemampuan berpikir kritis siswa 


\section{HASIL DAN PEMBAHASAN}

Pengukuran kemampuan awal siswa pada penelitian ini menggunakan nilai ulangan harian pada bab sebelumnya disajikan pada tabel berikut.

Tabel 4.1 Kemampuan Awal

\begin{tabular}{lcc}
\hline Kelas & Jumlah Sampel & Rata-rata \\
\hline Eksperimen & 28 & 74,9 \\
\hline Kontrol & 29 & 70,2 \\
\hline
\end{tabular}

Untuk mengetahui kesamaan antara kelas eksperimen dan kontrol maka dilakukan uji $t$. Sebelum diujikan terlebih dahulu dilakukan uji homogenitas dan normalitas.

Tabel 4.2 Nilai Uji T

\begin{tabular}{lll}
\hline \multicolumn{3}{c}{ Kemampuan Awal } \\
\hline Sig & $\mathrm{t}_{\text {hitung }}$ & $\mathrm{t}_{\text {tabel }}$ \\
\hline .290 & 1,140 & 2,004045 \\
\hline
\end{tabular}

Berdasarkan data diatas diketahui bahwa taraf signifikan 0,05 lebih kecil dari nilai signifikan $(0,290)$ dan nilai $t_{\text {hitung }}(1,140)<t_{\text {tabel }}(2,004045)$. Disimpulkan bahwa pada kelas eksperimen dan kontrol kemampuan awal siswa memiliki kesamaan.

1. Perbedaan Berpikir kritis antara Siswa yang Belajar Menggunakan Model PBL dengan Pendekatan Multiple Representation dan Siswa yang Belajar Menggunakan Model Problem Based Learning.

Setelah kedua kelas yakni eksperimen dan kontrol diberi perlakuan maka diperoleh data kemampuan berpikir kritis siswa. Model PBL diberikan pada kelas kontrol dan PBL dengan pendekatan multipe representation pada kelas eksperimen yang hasilnya disajikan pada tabel berikut.

Tabel 4.3 Nilai Kemampuan Berpikir Kritis

\begin{tabular}{clcccc}
\hline \multicolumn{1}{c}{ Kelas } & \multicolumn{1}{c}{ Model } & $\begin{array}{l}\text { Jumlah } \\
\text { sampel }\end{array}$ & $\begin{array}{c}\text { Nilai } \\
\text { Max }\end{array}$ & $\begin{array}{c}\text { Nilai } \\
\text { Min }\end{array}$ & Rata-rata \\
\hline Eksperimen & $\begin{array}{l}\text { Model PBL dengan pendekatan } \\
\text { Multiple Representation }\end{array}$ & 28 & 95 & 60 & 78,8 \\
\hline Kontrol & Model PBL & 29 & 87 & 55 & 74,1 \\
\hline
\end{tabular}

Hasil menunjukan bahwa rata-rata nilai tertinggi dari kemampuan berpikir kritis yaitu pada kelas eksperimen. Selanjutnya dengan uji normalitas menggunakan Kolmogorov Smirnov menunjukan nilai yang signifikan dari kelas ekperimen $(0,200)>$ taraf signifikan $(0,05)$, sedangkan kelas kontrol 0,05 $<0,065$. Berdasarkan hasil uji kemampuan berpikir kritis siswa terdistribusi normal. Uji homogenitas menunjukan bahwa data homogen melalui nilai sig. > taraf sig. $(0,05<0,348)$,

Langkah selanjutnya yaitu uji hipotesis melalui ANOVA dua jalur dengan taraf signifikan 0,05, menggunakan SPSS Window for 16.0. Hasil analis dan uji statistik diketahui bahwa taraf signifikansi $(0,05)>$ nilai signifikan $(0,000)$. Diartikan $\mathrm{H}_{01}$ ditolak dan $\mathrm{H}_{11}$ diterima, maka kemampuan berpikir kritis antara siswa belajar menggunakan PBL dengan pendekatan multiple representation dan belajar melalui model PBL menunjukan perbedaan yang signifikan. Penemuan ini sesuai penelitian terdahulu yang mengungkapkan bahwa kemampuan berpikir kritis siswa mengalami peningkatan dengan penerapan model PBL (Fitriyyah \& Wulandari, 
2019; Farisi et al., 2017; Rahayu, Ismail \& Hasan, 2016). Sejalan dengan itu hasil peneltian Marpaung \& Simanjuntak (2018); Khotimah et al., (2017) juga menyatakan bahwa peningkatan kemampuan berpikir kritis siswa juga dipengaruhi oleh penggunaan multiple representation dalam prose pembelajaran.

Perbedaan ini ditujukan karena pada tahap awal kelas eksperimen siswa dihadapkan pada masalah konkrit yang disajikan dengan berbagai representasi yang relevan seperti masalah fisika yang ditampilkan dalam bentuk video dan gambar selain yang diungkapkan dengan katakata seperti biasanya. Sedangkan kelas kontrol pada tahap awal siswa dihadapkan pada masalah konktir yang hanya disajikan dengan menggunakan kata-kata. Tahap kedua pada kelas eksperimen, mengorganisasi siswa melalui demonstrasi menggunakan representasi verbal, matematis dan gambar dalam kegiatan diskusi sedangkan pada kelas kontrol guru mengorganisasi siswa melalui demonstrasi dengan hanya menggunakan representasi verbal.

Pada langkah ketiga, kedua kelas diberi perlakuan yang sama yaitu membimbing siswa melakukan percobaan menyelesaikan masalah yang disajikan, perbedaan yang terjadi yaitu pada kelas kontrol masalah yang diterangkan masih bersifat abstrak sedangkan pada kelas eksperimen masalah ditampilkan dengan menggunakan video pembelajaran dan LKS pada kelas eksperimen juga menampilkan LKS multiple representation. Tahap keempat, pada langkah ini siswa di kelas eksperimen memecahkan dan menyajikan masalah dengan berbagai representasi sedangkan pada kelas kontrol siswa memecahkan dan menyajikan masalah dengan hanya menggunakan satu representasi saja. Faktor lain yang membedakan kemampuan berpikir kritis siswa yaitu daya analisis siswa pada pemecahan masalah kurang maksimal. Dengan adanya kemampuan analisis yang baik maka akan berdampak pada pengembangan kemampuan berpikir kritis yang baik pula (Rahmat, Sumarwa \& Santoso, 2019).

Pembelajaran dengan menggunakan pendekatan multiple representation dalam ilmu fisika dapat memberikan kesempatan yang lebih baik bagi siswa dalam mengkomunikasi dan memahami konsep-konsep dan juga mengetahui bagaimana mereka bekerja dengan proses fisika dan sistem fisika (Fredlund, Airey \& Linder, 2015). Penanaman konsep fisika yang ditampilkan dalam berbargai representasi dapat membantu siswa dalam materi yang diajarkan (Mahardika, 2016). Hal ini dikarenakan kemampuan spesifik yang berbeda dari masing-masing siswa dalam memahami konsep fisika, sehingga sajian meteri harus menggunakan berbagai representasi.

Penggunaan model PBL dengan pendekatan multiple representation dalam penelitian ini memberi pengaruh yang positif dalam kemampuan berpikir kritis siswa. Hasbullah et al. (2018), mengungkapkan bahwa multiple representation dapat membangun pemahaman dengan memberikan materi dari berbagai bentuk yang disajikan. Hal ini dilihat dari antusias siswa dalam menjawab pertanyaan selama pembelajaran berlangsung. Misalnya, saat pengajar menampilkan masalah fisika dengan representasi gambar dan pengajar memberikan pertanyaan mengenai konsep yang berhubungan dengan gambar tersebut siswa berlomba-lomba untuk menjawab, selain itu saat menanyakan konsep yang dipelajari siswa sebelumnya, siswa masih bisa menjawab dengan benar. Hal ini karena semakin banyak representasi yang disajikan semakin baik pula ingatan siswa terhadap materi yang diajarkan (Nurazmi, 2019). Pada tahap diskusi kelompok, siswa diberikan LKS multiple representation dan siswa harus menggunakan berbagai representasi dalam menjawab permasalahan yang ada di LKS tersebut. Saat mengerjakan LKS siswa tidak banyak bertanya karena penggunaan berbagai representasi dalam mengerjakan soal diskusi dapat membantu siswa memahami dan menganalisis soal, sehingga dapat menyelesaikan dengan baik soal diskusi dalam LKS. Hal ini sejalan dengan temuan Yuliana, Rudibyani \& Evkar (2018) dalam penelitiannnya mengenai penggunaan LKS multiple representation mampu meningkatkan pengusaan dan pemahaman konsep siswa pada pembelajaran Sains. Saat mengerjakan soal ulangan, siswa tidak kesulitan dalam mengerjakan 
soal dan menyelesaikan soal tepat waktu. Peran pembelajaran multiple representation terhadap pemahaman konsep fisika membantu siswa mudah menangkap materi berupa kinsep dan prinsip fisika (Nurazmi, 2019). Penggunaan model PBL dengan pendekatan multiple representation, siswa mampu melakukan penyelidikan, mengevaluasi, menganalisis, menciptakan dan mengembangkan kemampuan sesuai gaya belajar yang dimiliki (Arizkah, Herman \& Palloan, 2018; Nurazmi, 2019).

Penerapan model PBL pada kelas kontrol, masalah yang ditampilkan dalam bentuk reprsentasi verbal saja. Setiap siswa memilki kemampuan representasi yang berbeda dalam memahami suatu masalah yang berdampak pada kemampuan siswa dalam menganalisis persoalan (Mahardika, 2016). Ditemukan bahwa antusias siswa untuk menjawab pertanyaan masih rendah, karena masih terdapat siswa yang kesulitan memahami masalah sehingga sulit menemukan solusi yang tepat. Pada saat peneliti menanyakan konsep fisika yang telah dipelajari pada materi sebelumnya, hanya sebagian kecil siswa yang bisa menjawab, sedangkan yang lainnya tidak mengingat kembali materi maupun konsep yang telah dipelajari.

Pada tahap mengerjakan soal, siswa kesulitan sehingga waktu yang dibutukan relatif lama bahkan sebagaian besar siswa tidak mampu menyelesaikan semua masalah yang diajukan dengan tepat waktu. Faktor lain yang menyebabkan hal tersebut yaitu siswa tidak dapat mengalisis maksud soal dan kurang mampu menghubungkan masalah kedalam rumus yang tepat (Noer \& Gunowibowo, 2018). Hal lain juga dipengaruhi oleh kebiasaan siswa yang kurang mampu menyelesaikan soal matematis yang non rutin atau tidak bervariasai dan hanya menggunakan rumus matematis dalam penyelesaian soal (Sundaygara \& Gaharin, 2017; Noer \& Gunowibowo, 2018). Selain itu, saat mengerjakan LKS banyak siswa yang tidak mengerti sehingga siswa selalu bertanya dan meminta penjelasan tambahan terkait pengerjaan soal di LKS serta siswa membutuhkan waktu yang lama dalam mengerjakan LKS, bahkan ada kelompok yang semua soal tidak terselesaikan dalam waktu yang ditentukan.

Temuan diatas sesuai dengan hasil temuan peneliti sebelumnya pada kelas kontrol yang menyatakan bahwa kendala siswa dalam penyelesaian masalah dikarenakan daya analisis masalah dan pemahaman siswa terhadap masalah belum maksimal (Sundaygara \& Gaharin, 2017). Oleh sebab itu dengan tujuan agar siswa mampu memecahkan masalah dengan baik dierlukan implementasi pendekatan multiple representasi dalam pelaksanaan model PBL (Sundaygara \& Gaharin, 2017; Larasati et al., 2019; Nurazmi, 2019).

2. Perbedaan Kemampuan Berpikir Kritis Siswa yang Berkemampuan Kolaborasi Tinggi dengan Siswa yang Kemampuan Kolaborasi Rendah.

Kemampuan kolaborasi dinilai dengan menggunakan rubrik penskoran dengan skala 1-3.

Tabel 4.4 Data Kemampuan Kolaborasi Kelas Eksperimen dan Kelas Kontrol

\begin{tabular}{lllll}
\hline Kelas & Jml sampel & \multicolumn{2}{l}{ Nilai Kemampuan kolaborasi } & Rata-rata \\
& & Tertinggi & Terendah & \\
\hline Eksperimen & 28 & 93 & 53 & 74 \\
\hline Kontrol & 29 & 87 & 47 & 68,3 \\
\hline
\end{tabular}

Kemampuan kolaborasi yang dimiliki siswa juga mempengaruhi kemampuan berpikir kritis. Siswa yang berkemampuan kolaborasi tinggi memiliki prestasi belajar yang tinggi begitupun sebaliknya, seperti yang ditunjukan dalam tabel berikut:

Tabel 4.5 Perbandingan Nilai Kemampuan Kolaborasi dengan Kemampuan Berpikir Kritis

\begin{tabular}{lcc}
\hline Kelas & Kemampuan Kolaborasi & Kemampuan Berpikir Kritis \\
\hline Eksperimen & 74 & 78,8 \\
\hline Kontrol & 68,3 & 74 \\
\hline
\end{tabular}


Hasil analisis anaova dua jalur, diperoleh taraf signifikansi $(0,05)>$ nilai signifikan $(0,000)$. Disimpulkan terdapat perbedaan kemampuan berpikir kritis antara siswa yang mempunyai kemampuan kolaborasi tinggi dengan rendah. Sejalan dengan penelitian yang dilakukan oleh Fitriyani et al. (2019) mengungkapkan bahwa keterampilan kolaborasi merupakan keterampilan yang penting untuk mencapai hasil yang efektif. Dengan berkolaborasi siswa memiliki kemampuan sosial dan bekerja sama untuk mencapai tujuan pembelajaran. Burke, 2011 dalam Puspita, Wahyuni \& Yushardi, (2017) juga mengungkapkan bahwa pembelajaran dengan berkolaborasi dapat meningkatkan nilai dan mengembangkan keterampilan kerja sama siswa.

Kemampuan kolaborasi diukur dengan menggunakan lima aspek. Adapun nilai kemampuan kolaborasi untuk kedua kelas pada setiap aspeknya dijelaskan dalam grafik dibawah ini.

Grafik 1 Histogram Nilai Setiap Aspek Kemampuan Kolaborasi

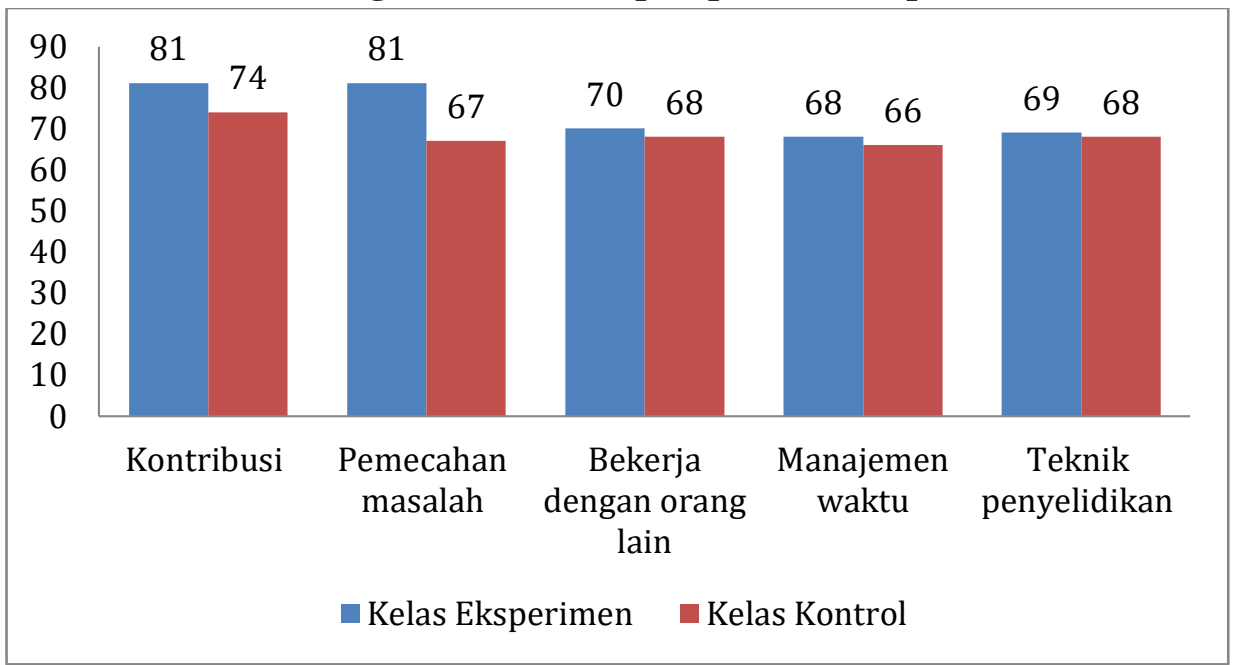

Dari grafik diatas terlihat jelas bahwa kemampuan kolaborasi berpengaruh pada kemampuan berpikir kritis siswa begitupun sebaliknya,hal ini dilihat dari hubungan aspek kemampuan kolaborasi dengan kemampuan berpikir kritis. Misalnya pada aspek kontribusi, siswa berusaha menggunakan pikirannya dalam menemukan ide sehingga dapat menganalisis argumen dan memberikan penjelasan dasar terhadap masalah. Ini sesuai dengan teori Hermawan et al. (2017), mengungkapkan bahwa aspek kontribusi menerangkan bagaimana karakteristik siswa dalam menjelaskan gagasan dan berpartisipasi aktif dalam diskusi dengan tim. Selain itu, pada aspek pemecahan masalah sebagian besar siswa terlibat aktif dan antusias dalam menemukan ide untuk memecahkan persoalan, meskipun mengalami kesulitan namun siswa berusaha untuk mengatasinya. Dengan demikian siswa dapat menyimpulkan dan memberikan penjelasan lanjurtan mengenai permasalahan (Pradana, Parno \& Handayanto, 2017).

Manajemen waktu menjelaskan karakter siswa dalam menyelesaikan suatu tugas baik secara individu maupun kelompok dalam waktu yang tepat (Hermawan et al., 2017). Pada aspek ini siswa mampu menyelesaikan semua persoalan sesuai waktu yang ditentukan, sehingga persoalan dapat diselesaikan dengan baik dan dapat membuat kesimpulan dari setiap permasalahan. selanjutnya pada aspek bekerja sama dengan orang lain siswa berdiskusi, bertukar ide dengan individu lainnya kemudian siswa mengumpulkan ide-ide berbeda yang dihasilkan dalam kelompok sehingga siswa dapat mengambil kesimpulan, membuat strategi dan taktik dalam memilih ketepatan solusi penyelesaian masalah. Hal ini didukung oleh kriteria dari kemampuan kolaborasi yang diadopsi oleh (Widodo, Jatmiko, Santia \& Katminingsih, 2019), mengungkapkan bahwa dalam berkolaborasi siswa harus berusaha mendengarkan, berbagi 
dengan yang lain dan selalui memberi dukungan yang terbaik bagi teman kelompok serta menentukan keputusan secara bersama dalam penyelesaian masalah.

Aspek penyeledikan merupakan menyampaukan bentuk sikap siswa, yaitu usaha siswa mengumpulkan berbagai solusi dari sumber yang bervariasi dalam pemecahan masalah (Hermawan et al., 2017). Pada aspek ini, siswa melakukan observasi dan mencari solusi penyelesaian masalah dari berbagai sumber seperti mendaatkan informasi dari buku dan modul. Dengan demikian melalui berbagai sumber yang digunakan siswa mampu menghubungkan dan membangun keterampilan untuk memecahkan masalah (Sulardi et al, 2015; Miroh et al., 2019).

Kemampuan individu dalam kelompok kecil untuk bekerja sama mencapai tujuan pembelajaran yang dimanifestasikan dalam bentuk interaksi sosial biasa disebut kemampuan kolaborasi (Muiz, Wilujeng, Jumadi \& Senam, 2016). Kemampuan kolaborasi yang baik akan memudahkan siswa memecahkan masalah yang sulit, karena siswa bekerja sama dalam memecahkan masah. Dengan bekerja sama apa yang sebelumnya tidak terpikirkan bisa saja muncul dalam pikiran. Pengetahuan dan perspektif yang berbeda dari setiap individu dalam kelompok bisa memberi inspirasi untuk pemecahan masalah bersama (Suyatna, 2017). Sebaliknya siswa yang memiliki kemampuan kolaborasi rendah, tidak dapat memecahkan masalah dengan mudah karena cenderung memecahkan masalah dengan mengandalkan pengetahuan dan perspektif dari satu indivudu, sehingga tidak ada masukan dan inspirasi untuk memecahkan masalah. Dengan dasar dua kepala lebih baik daripada satu kepala maka kolaborasi sangat penting dalam memecahkan masalah dan memperoleh hasil belajar yang maksimal (Suyatna, 2017). Jika siswa mampu memecahkan masalah maka siswa tersebut sudah mampu berpikir kritis, karena dasar untuk memahami, menganalisis dan memecahkan masalah adalah memiliki keterampilan berpikir kritis (Dewi, Mudakir \& Murdiyah, 2016). Dengan demikian kemampuan kolaborasi sangat penting dalam meningkatkan kemampuan berpikir kritis siswa.

\section{Pengaruh Interaksi Problem Based Learning dengan Pendekatan Multiple Representation dan Kemampuan Kolaborasi Terhadap Kemampuan Berpikir Kritis.}

Hasil analisis uji statistik anova dengan bantuan SPSS 16.0 menunjukan bahwa ada interaksi model PBL dengan pendekatan multiple representation dan kemampuan kolaborasi terhadap kemampuan berpikir kritis siswa, yang ditunjukan oleh hasil analisis $F_{\text {hitung }}>F_{\text {tabel }}$ $(4,378>3,165)$ dengan nilai signifikan $(0,044)>$ taraf signifikan $(0,05)$, yang berarti ada interaksi antara model pembelajaran dan kemampuan kolaborasi terhadap kemampuan berpikir kritis. 


\section{Estimated Marginal Means of Kemampuan Berpikir Kritis}

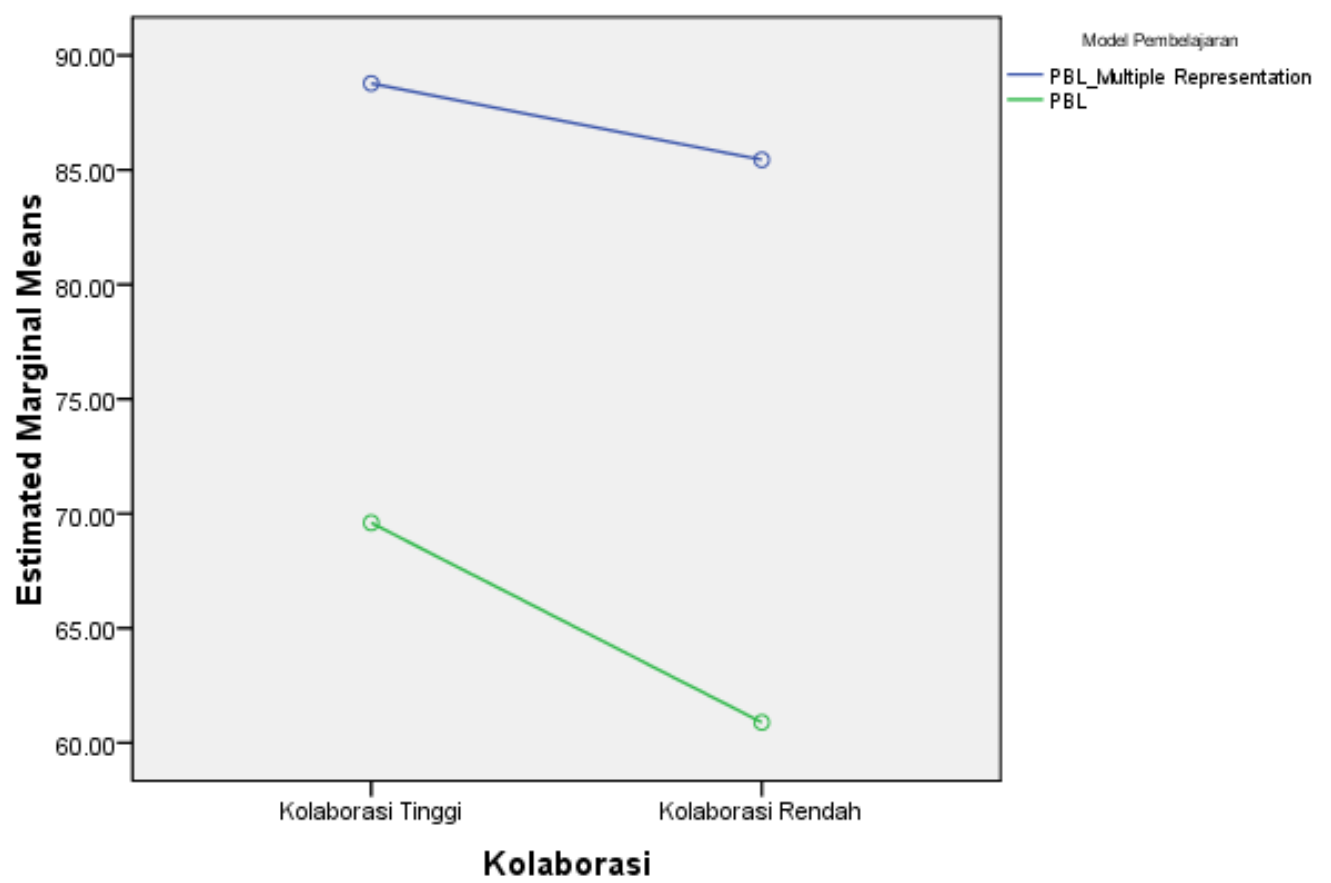

Gambar 2 Interaksi Model PBL dengan Pendekatan Multiple Representasi dan Kemampuan Kolaborasi

Dari gambar diatas juga menunjukan bahwa adanya pengaruh interaksi antara model PBL dengan pendekatan multiple representation dan kemampuan kolaborasi terhadap kemampuan berpikir kritis. Sejalan dengan penelitian terdahulu penelitian menunjukkan bahwa implementasi PBL dengan pendekatan multiple representation mampu meningkatkan keterampilan berpikir kritis sehingga masalah dapat diselesaikan dengan baik (Rahmat, Suwarma \& Imansyah, 2019). Penelitian sebelumnya juga yang dilakukan oleh Sundaygara \& Gaharin (2017), mengungkapkan bahwa model PBL melalui pendekatan multiple representation dapat meningkatkan pemahaman konsep siswa. Penggunaan multiple representation memberi kesempatan bagi siswa untuk meningkatkan pemahaman konsep fisika melalui proses yang bervariasi, karena guru menyampaikan sebuah konsep tidak hanya menggunakan satu representasi saja melainkan berbagai representasi dengan maksud membuat tersebut semakin jelas (Nurazmi, 2019). Kemapuan berpikir kritis siswa dapat dibentuk atau dampak dari pemahaman konsep yang benar dan keterampilan memecahkan masalah (Fitriyani et al., 2019).

Dalam penelitian ini selain model pembelajaran, kemampua kolaborasi juga memiliki pengaruh pada kemampuan siswa dalam berpikir kritis. Hasil yang diperoleh sesuai temuan penelitian Suyatna (2017), jika siswa memiliki kemampuan kolaborasi tinggi maka siswa memiliki kemampuan memecahkan masalah dengan baik, karena dengan berkolaborasi siswa dapat menggabungkan setiap perspektif dan pengetahuan yang berbeda dari setiap individu serta mampu menemukan ide baru untuk memecahkan masalah. Perbedaan perspektif pada suatu konsep akan memungkinkan siswa berpikir kreatif, kritis dan mampu berkomunikasi dengan sesama untuk memiliki kesimpulan individu (Anwar, Munzil \& Hidayat, 2017). Dalam proses pembelajaran fisika ditekankan bahwa kemampuan kolaborasi sangat penting, karena dalam pembelajaran fisika siswa melakukan kegiatan praktikum untuk mengetahui dan memahami konsep secara mendalam dan melakukan investigasi permasalahan yang diberikan guru 
kemudian merencanakan dan memecahkan masalah secara kelompok, sehingga siswa dituntut untuk memiliki kemampuan kolaborasi (Hermawan et al.,2017). Hal ini diprediksi ketika bekerja secara berkelompok maka hasilnya lebih efektif jika dibandingkan dengan bekerja secara individu (Anwar et al., 2017).

Penerapan model PBL dengan pendekatan multiple representation pada pembelajaran fisika dapat memudahkan dalam melatih keterampilan siswa untuk berpikir kritis, karena pada proses belajar berkaitan langsung dengan persoalan yang kontekstual yang berhubungan dengan materi pembelajaran yang disajikan dengan berbagai representasi sehingga siswa mengerti dan menyadari tujuan mereka belajar dan kemudian mengidentifikasi masalah dan mengumpulkan informasi dari berbagai sumber serta melakukan penyelidikan (Marpaung \& Simanjuntak, 2018). Penggunaan berbagai representasi dalam pembelajaran fisika dapat meminimalisir kesulitan siswa dalam mempelajari dan menyelesaikan masalah fisika. Seperti yang diungkapkan oleh Brener dalam Widianingtiyas, Siswono \& Bakri (2015), bahwa keberhasilan siswa dalam menyelesaikan persoalan tergantung pada bagaimana suatu siutuasi direpresentasikan keterampilan merepresentasikan masalah, seperti penggunaan kata-kata, tabel, grafik dan persamaan-persamaan, penyelesaian dan manipulasi simbol dalam matematika. Hal ini diperkuat oleh tiga fungsi utama penerapan multiple representation seperti; melengkapi informasi, membatasi interpretasi dan membangun pemahaman (Ainsworo dalam (Widianingtiyas et al., 2015).

Proses saling bekerja sama yang disenut kolaborasi, berkordinasi, memberikan pengaruh ketergantungan yang positif kepada setiap kelompok yang mengarah pada tujuan bersama (Lelasari, Setyosari \& Ulfa, 2017). Dengan berkolaborasi siswa mampu menemukan ide-ide yang kreatif untuk menyelesaikan masalah, karena dalam berkolaborasi siswa bertukar ide untuk menyelesaikan persoalan dan dapat berinteraksi secara aktif, menyenangkan dan saling memberi motivasi (Miroh et al., 2019). Berkaitan dengan kemampuan kolaborasi, siswa sebaiknya menggunakan berbagai representasi. Penggunaan berbagai representasi dalam menjawab permasalahan juga membantu siswa menganalisis dan menyelesaikan masalah dengan tepat. Siswa yang berkemampuan berpikir kritis dengan baik jika siswa mampu menganalisis dan menyelesaikan masalah dengan baik (Rahmat et al., 2019).

\section{KESIMPULAN}

Hasil penelitian ini dapat disimpulkan sebagai berikut:

1. Ada perbedaan kemampuan berpikir kritis antara siswa yang belajar menggunakan model problem based learning dengan pendekatan multiple representation dengan siswa yang hanya belajar menggunakan model problem based learning.

2. Memiliki perbedaan berpikir kritis antara siswa yang memiliki kemampuan kolaborasi tinggi dengan siswa yang memiliki kemampuan kolaborasi rendah.

3. Terdapat interaksi antara model proble based learning dengan pendekatan multiple representation dan kemampuan kolaborasi terhadap kemampuan berpikir kritis.

\section{SARAN}

1. Pendidik dapat menggunakan model PBL dengan pendekatan multiple representation pada kegiatan belajar mengajar fisika yakni peserta didik dberperan aktif. Dan kemampuan kolaborasi juga hendaknya diperhatikan, karena kemampuan kolaborasi dapat mempengaruhi kemampuan berpikir kritis.

2. Peneliti lain yang ingin menggunakan model PBL dengan pendekatan multiple representation dan kemampuan kolaborasi diharapkan menggunakan model pembelajaran yang lain. 


\section{DAFTAR PUSTAKA}

Al-Fikry, I., Yusrizal, Y., \& Syukri, M. (2018). Pengaruh Model Problem Based Learning Terhadap Kemampuan Berpikir Kritis Peserta Didik Pada Materi Kalor. Jurnal Pendidikan Sains Indonesia, 6(1), 17-23. https://doi.org/10.24815/jpsi.v6i1.10776

Anwar, B., Munzil, \& Hidayat, A. (2017). Pengaruh Collaborative Learning dengan Teknik Jumping Task Terhadap Keterampilan Berpikir Kritis dan Hasil Belajar Siswa. Jurnal Pembelajaran Sains, 1(2), 15-25. http://journal2.um.ac.id/index.php/

Ardiansyah, S., Ertikanto, C., \& Rosidin, U. (2019). Pengaruh Penggunaan Modul Pembelajaran Kontekstual Berbasis Multiple Representations Pada Materi Fluida Statis Terhadap Kemampuan Berpikir Kritis Siswa. JPF Jurnal Pendidikan Fisika, VII(2), 265-278.

Arizkah, N., Herman, \& Palloan, P. (2018). Penerapan Pembelajaran Berbasis Masalah Terhadap Keterampilan Berpikir Kritis Peserta Didik SMAN 5 Soppeng. Jurnal Sains Dan Pendidikan Fisika (JSPF), 14(3), 52-63.

Dewi, M. R., Mudakir, I., \& Murdiyah, S. (2016). Pengaruh Model Pembelajaran Kolaboratif Berbasis Lesson Study terhadap Kemampuan Berpikir Kritis Siswa. The Effect of Collaborative Learning Model with Lesson Study on Student Critical Thingking. Jurnal Edukasi Unej, III(2), 29-33. https://doi.org/10.19184/jukasi.v3i2.3526

Doyan, A., Taufik, M., \& Anjani, R. (2018). Pengaruh Pendekatan Multi Representasi Terhadap Hasil Belajar Fisika Ditinjau Dari Motivasi Belajar Peserta Didik. Jurnal Penelitian Pendidikan IPA (JPPIPA), 4(1), 35-45. https://doi.org/10.29303/jppipa.v4i1.99

Farisi, A., Hamid, A., \& Melvina. (2017). Pengaruh Model Pembelajaran Problem Based Learning Terhadap Kemampuan Berpikir Kritis dalam Meningkatkan Hasil Belajar Siswa Pada Konsep Suhu dan Kalor. Jurnal Ilmiah Mahasiswa (JIM) Pendidikan Fisika, 2(3), 283-287. http://www.jim.unsyiah.ac.id/pendidikan-fisika/article/view/4979

Fitriyani, D., Jalmo, T., \& Yolida, B. (2019). Penggunaan Problem Based Learning untuk Meningkatkan Keterampilan Kolaborasi dan Berpikir Tingkat Tinggi. Jurnal Bioterdidik, 7(3), 77-87.

Fitriyyah, S. J., \& Wulandari, T. S. H. (2019). Effect of Problem Based Learning Model on Critical Thinking of Junior High School Students on Biology Learning Global Material. BIOEDUKASI: Jurnal Pendidikan Biologi, 12(1), 1-7.

Fredlund, T., Airey, J., \& Linder, C. (2015). Enhancing the Possibilities for Learning: Variation of Disciplinary-Relevant Aspects In Physics Representations. European Journal of Physics, 36, 1-11. https://doi.org/10.1088/0143-0807/36/5/055001

Haryanti, Y. D. (2017). Model Problem Based Learning Membangun Kemampuan Berpikir Kritis Siswa Sekolah Dasar. Jurnal Cakrawala Pendas, 3(2), 57-63. https://doi.org/10.31949/jcp.v3i2.596

Hasbullah, H., Halim, A., \& Yusrizal, Y. (2018). Penerapan Pendekatan Multi Representasi Terhadap Pemahaman Konsep Gerak Lurus. Jurnal IPA \& Pembelajaran IPA, 2(2), 6974. https://doi.org/10.24815/jipi.v2i2.11621

Hermawan, H., Siahaan, P., Suhendi, E., Kaniawati, I., Samsudin, A., Setyadin, A. H., \& Hidayat, S. R. (2017). Desain Instrumen Rubrik Kemampuan Berkolaborasi Siswa SMP dalam Materi Pemantulan Cahaya. Jurnal Penelitian \& Pengembangan Pendidikan Fisika, 3(2), 167-174. https://doi.org/10.21009/1.03207

Khotimah, K., Nyeneng, I. D. P., \& Sesunan, F. (2017). Pengaruh Kemampuan Berpikir Kritis dan Respon Bahan Ajar Multiple Representation Terhadap Hasil Belajar. Jurnal Pembelajaran Fisika, 5(3).

Larasati, A. D. P., Ibnu, S., \& Santoso, A. (2019). Model Problem Based Learning dengan Pendekatan Multi Representasi untuk Meningkatkan Kemampuan Memecahkan Masalah Siswa dengan Tingkat Self-Efficacy Berbeda. Jurnal Pendidikan: Teori, Penelitian, Dan Pengembangan, 4(6), 828-834.

Lelasari, M., Setyosari, P., \& Ulfa, S. (2017). Pemanfaatan Social Learning Network dalam Mendukung Keterampilan Kolaborasi Siswa. TEP \& PDs Transformasi Pendidikan Abad $21,167-172$.

Mahardika, I. K. (2016). Penggunaan Pendekatan Multirepresentasi dengan Setting Quantum Teaching dalam Pembelajaran Gerak Melingkar dan Dampaknya Terhadap Pemahaman 
Konsep Mahasiswa Calon Guru Fisika. SEMINAR NASIONAL PENDIDIKAN 2016"Peran Pendidikan, Sains, Dan Teknologi Dalam Membangun Intelektual Bangsa Dan Menjaga Budaya Nasional Di Era MEA," 1, 545-554.

Marpaung, N., \& Simanjuntak, M. P. (2018). Desain Pembelajaran Berbasis Masalah dan Multipel Representasi Terhadap Hasil Belajar dan Keterampilan Berpikir Kritis. INPAFI (Inovasi Pembelajaran Fisika), 6(3), 40-45. https://doi.org/10.24114/inpafi.v6i3.11119

Miroh, Patonah, S., \& Kaltsum, U. (2019). Pengaruh Model Pembelajaran Team Games Tournament ( TGT ) terhadap Kemampuan Kolaborasi Siswa di SMPN 5 Ungaran. Prosiding Seminar Nasional The 5th Lontar Physics Forum, 113-118.

Mustajab, W., Hadi Senen, S., \& Waspada, I. (2018). Analisis Kemampuan Berpikir Kritis Siswa SMA Pada Materi Koperasi. OIKOS Jurnal Kajian Pendidikan Ekonomi Dan Ilmu Ekonomi, II(1), 52-56. https://doi.org/10.23969/oikos.v2i1.920

Noer, S. H., \& Gunowibowo, P. (2018). Efektivitas Problem Based Learning Ditinjau Dari Kemampuan Berpikir Kritis dan Representasi Matematis. Jurnal Penelitian Dan Pembelajaran Matematika, 11(2), 17-32. https://doi.org/10.30870/jppm.v11i2.3751

Novtiar, C., \& Aripin, U. (2017). Meningkatkan Kemampuan Berpikir Kritis Matematis dan Kepercayaan Diri Siswa SMP Melalui Pendekatan Open Ended. PRISMA, VI(2), 119-131. https://doi.org/10.35194/jp.v6i2.122

Nurazmi. (2019). Pengaruh Pembelajaran Multi-Representasi Terhadap Pemahaman Konsep Fisika Ditinjau Dari Locus Of Control. Jurnal Pendidikan Fisika, 7(2), 127-132.

Nurkholifah, \& Mayasari, T. (2018). Profil Kemampuan Berpikir Kritis Pelajaran Fisika Siswa SMP. Prosiding Seminar Nasional Quantum, 25, 569-574.

Pradana, S. D. S., Parno, \& Handayanto, S. K. (2017). Pengembangan Tes Kemampuan Berpikir Kritis Pada Materi Optik Geometri untuk Mahasiswa Fisika. Jurnal Penelitian Dan Evaluasi Pendidikan, 21(1), 51-64. https://doi.org/10.21831/pep.v21i1.13139

Puspita, I. A., Wahyuni, S., \& Yushardi. (2017). Pengembangan Lembar Kerja Siswa (LKS) Fisika Berbasis CTL (Contextual Teaching and Learning) untuk Meningkatkan Prestasi Collaborative Skills Siswa SMA. Jurnal Pembelajaran Fisika, 6(4), 376-382. https://doi.org/10.20961/prosidingsnfa.v2i0.16420

Rahayu, Ismail, S., \& M.hasan. (2016). Pengaruh Model Problem Based Learning Terhadap Berpikir Kritis Dan Hasil Belajar Elastisitas Siswa Kelas Xi Sma Negeri 7 Banda Aceh. Jurnal Pendidikan Sains Indonesia, 4(2), 105-116. https://doi.org/10.24815/jpsi.v4i1.6589

Rahmat, R., Suwarma, I. R., \& Imansyah, H. (2019). Penerapan Model Pembelajaran Problem Based Learning Berbasis Multirepresentasi Untuk Meningkatkan Kemampuan Berpikir Kritis Siswa SMA Pada Materi Getaran Harmonik. Prosiding Seminar Nasional Fisika (EJournal) SNF2019, VIII, 101-106. https://doi.org/10.21009/03.snf2019.01.pe.13

Respatiningrum, N., Sunardi, \& Akhyar, M. (2017). Penggunaan Model Inkuiri Terbimbing Untuk Meningkatkan Kemampuan Berpikir Kritis Fisika Siswa SMA. Teknodika, Jurnal Penelitian Teknologi Pendidikan, 15(2), 58-64.

Sipayung, H. D., Rahmatsyah, Sani, R. A., Bunawan, W., \& Lubis, R. H. (2019). Pengaruh Model Pembelajaran Collaborative Inquiry Terhadap Keterampilan 4C Siswa di SMA. Jurnal Pendidikan Fisika, 8(1), 29-38.

Sulardi, Nur, M., \& Widodo, W. (2015). Pengembangan Perangkat Pembelajaran Fisika Model Problem Based Learning (PBL) untuk Melatih Keterampilan Berpikir Kritis Siswa. Pendidikan Sains Pascasarjana Universitas Negeri Surabaya, 5(1), 802-810.

Sundaygara, C., \& Gaharin, D. (2017). Pengaruh Multiple Representation pada Pembelajaran Berbasis Masalah Terhadap Penguasaan Konsep Fisika Dasar II Mahasiswa Fisika. Momentum: Physics Education Journal, 1(2), 111-121. https://doi.org/10.21067/mpej.v1i2.1863

Suyatna, A. (2017). Membangun Kemampuan Berpikir Kritis, Kreatif, Kolaboratis, Komunikatif Siswa Melalui Proses Pembelajaran (pp. 1-19).

Widianingtiyas, L., Siswoyo, S., \& Bakri, F. (2015). Pengaruh Pendekatan Multi Representasi dalam Pembelajaran Fisika Terhadap Kemampuan Kognitif Siswa SMA. Jurnal Penelitian \& Pengembangan Pendidikan Fisika, 1(1), 31-38. https://doi.org/10.21009/1.01105

Widodo, S., Jatmiko, Santia, I., \& Katminingsih, Y. (2019). Pemberdayaan Kemampuan 
Kolaborasi Mahasiswa Menggunakan Model Pembelajaran Student Teams Achievement Division. Jurnal Math Educator Nusantara: Wahana Publikasi Karya Tulis Ilmiah Di Bidang Pendidikan Matematika, 5(2), 182-189. https://doi.org/10.29407/jmen.v5i2.13795

Yuliana, D., Rudibyani, R. B., \& Evkar, T. (2018). Efektivitas LKS Berbasis Multipel Representasi dalam Meningkatkan Penguasaan Konsep Materi Larutan Elektrolit-Non Elektrolit. 